UDC 005.1

DOI: https://doi.org/10.30839/2072-7941.2019.177752

\title{
PHYLOSOPHY OF MANAGEMENT: EDUCATIONAL MEANINGS AND SOCIAL CHALENGES
}

\author{
(C) Vlasenko, Fedir \\ Taras Shevchenko National University of Kyiv (Kyiv, Ukraine) \\ E-mail vlasenkof@ukr.net, ORCID iD: 0000-0002-5272-9018 \\ (C) Levcheniuk, Yevheniia \\ Taras Shevchenko National University of Kyiv (Kyiv, Ukraine) \\ E-mail levchenyuk@ukr.net, ORCID iD: 0000-0002-0361-6455 \\ (C) Tovmash, Dmitry \\ Taras Shevchenko National University of Kyiv (Kyiv, Ukraine) \\ E-mail tovmash_d@ukr.net, ORCID iD: 0000-0002-4576-0703 \\ (C) Oleksyn, Igor \\ National University of Ukraine on Physical Education and Sport (Kyiv, Ukraine) \\ E-mail igoroleks@ukr.net, ORCID.http://orcid.org/0000-0002-6650-627X
}

\begin{abstract}
Aim. Disclosure of the theoretical and spiritual-practical potential of the philosophy of management in training specialists in the field of public management and administration. Methodology. In the research process there were used such methods as: analysis, synthesis, systemic, comparative, structural-functional and dialectical. The application of the synergistic approach to study management made it possible to consider the latter as a complex and open system. Results. The authors have proved that today the philosophy of management is a theoretical and methodological basis for modern managers' training. The emphasis is also put on the fact that the philosophy of management is different from the theory of management, since traditional management tries to implement the training program for a single manager, who should independently manage large teams and organizations. The authors are convinced that this statement is utopian nowadays. That is why the philosophy of management should appear as the methodological basis in the new paradigm of training managers of any level. Scientific novelty. For the first time in the scientific discourse, the attempt has been made to establish the status of the philosophy of management as one of the basic and obligatory disciplines in specialists' training for public and state administration and management. It is proved that the management of any systems becomes effective due to the interaction of three levels, namely: ideological, scientificmethodological and praxeological. The necessity of preparing managers as team members that adequately respond to current social challenges is identified as the main task of modern managerial education. The Practical Value. The research results should set the benchmarks for improving and creating a new system of modern managers' training, where the manager is not considered as a single leader (individual), but as a member of the team in which everyone is capital.
\end{abstract}

Key words: philosophy of management, management activity, management, education, paradigm.

Introduction

Current social practices require
including the management
phenomenon into the subject

(C) Vlasenko Fedir \& Levcheniuk Yevheniia \& Tovmash Dmitry \& Oleksyn Igor, 2019 
of philosophy, as management permeates all levels and spheres of social life and, therefore, creates a kind of unity where the individual is established as the subject and the surrounding world becomes the sphere of his or her conscious activity. It is the philosophical reflection of essence, meaning and values of management that appears to be the general theory and methodology of human managerial activity. The urgency of the philosophy of management is also determined by the fact that a number of disciplines are developing nowadays and management turns out to be the object of their study, for example, the management theory, sociology and management logics, management psychology, etc. But there are a lot of issues that still remain unresolved, such as, the problem of essence and functions of management, generalization of different approaches to management study, the issue of choice and justification of the most optimal methods of managerial activity and others. Therefore, philosophy, as a fundamental branch of knowledge, is designed to offer solutions to these issues of management.

Analysis of recent studies. Managing appears to be a kind of human activity the purpose of which is to transform an object according to the subject's vision of its development. In this sense, governance has existed since the human society was formed and it remains relevant today.

The new paradigm is being formed and established in the modern educational system of managers' training - that is the team system of management. The methodological principles of this paradigm were substantiated in the works of $K$. Matsushita and P. Drucker. The ideas of the new management model in the modern society were proposed by I. Adizes and F. Fukuyama. Lee Yacocca also suggested understanding management as an art and skill. He claimed every employee's involvement and interest in the teamwork is the determining factor in this process.

The purpose of the article is to reveal the essence as well as ideological, methodological and praxeological potential of the philosophy of management for training specialists in the field of managerial activity.

The methodology of this research involves complex analysis of management from the philosophical reflection standpoint which made it possible to conclude that the educational system of specialistsmanagers' training need to be reoriented. Management as a phenomenon of organization and direction of the society's development is derived from the management theory. Management is a purposeful human activity aimed at creating optimal functioning and development of the society, state, corporation, organization, family etc. It constantly requires constructive and creative thinking rather than using readymade, stereotyped approaches to solving specific problems in appropriate conditions. 
Summary of the research basic results. The phenomenon of management is an integral part of human existence, without which it is impossible to organize the people's coexistence, and society is a complex, self-organized system, where every element has knowledge, skills and abilities as well as personal desires, needs and interests. From this point of view, the essence of management is to find the unity and to direct the individual actions. In relation to that, A. Whitehead, a classic of the management theory, said, 'The social life is the problem of individual actions and the limits of their unity' [6, p. 417]. Thus, the development of the methodology for effective governance is an extremely important and complex task that we believe can be solved by philosophy. "The new concept of management aimed at sustainable development forms a new type of sustainable development economy based on the intellectual and creative component" [11, p.236].

Moreover, the world is intensely developing due to deployment of postglobalization processes. And establishing a new paradigm of education for managers is urgent for development of the world in general, for development of separate states, societies and the individual in particular. According to the wellknown modern sociologist F. Fukuyama, incompetence in management leads to serious consequences. “... incompetent or non-existent governments are becoming the source of serious problems, especially in the developing world $<>$ these problems are generated by the management weakness, as the main aspect of security" [7, p.6 - 8]. As F. Fukuyama states, it is quite actual nowadays that "the reason of the state weakness is also the fact that the science of public administration can not exist, despite the economists' recent efforts to create it [7, p.9]. It should be noted that the development of the state and society is not limited by the development of economy. Therefore, governance goes beyond the theory of management, and now the new paradigm of managers' training is being established according to which managers should not be regarded as flawless and ideal. Getting aware of that fact stimulates the transition from the tasks which can not be solved in management schools to the reorientation in the learning system from an individual to the team created by the manager thanks to his or her skills, and afterwards that team effectively works and solves the tasks he gives it.

Thus, the new paradigm of specialists-managers training must use innovative achievements and creative and non-standard approaches in the teaching process. Indeed, for a long time in the system of specialistsmanagers training the standardized, fixed methodologies and techniques have been used and their aim was to form a manager as a sole leader, who makes all important decisions himself. Moreover, management itself was considered only as a part of management theory. However, the use of ready-made methods and approaches to solving tasks has a number of threats and negative 
consequences for future managers. In particular, future managers become dependent on the clear set of wellknown methods and they can not distinguish the decisions that are taken automatically from those that require innovative approaches. It is also necessary to review radically the scientific and practical level of the lecture material and actualize it according to the new realities as much as possible by introducing the authors' courses, approaches and innovative methods corresponding to the modern social practice. For example, these are open lectures in the online mode of well-known modern theorists and practitioners of management, various trainings, master classes, etc.

One of the most authoritative modern theorists in the field of management, Western scientist I. Adizes, outlines a number of methodological principles that are extremely important for the management of any organization. In our opinion, the most important among them are three methodologically weighty points: 1) interaction between different people; 2) ideal people as well as ideal managers do not exist and can not exist; 3 ) everyone has to realize that changes are the basis and motive of any activity [1].

Expressing the fundamentals of the new education paradigm, the author focuses on the existing shortcomings. Namely, managers are not taught to make ream decisions. They are not taught how to resolve conflicts between people with different interests. A manager has to be ready for any changes. Herewith, he has to create new approaches and methods of making decisions to resolve conflicts, so practice is also a very important factor. Consequently, management is not only the theory. Practice and social reality turn out to be as important components as the theory.

According to the well-known modern Japanese businessman K.Matsushita, in the managerial activity, the determining factors are spiritual values, persistence, and purposefulness. The systemic nature of these factors directs the individual's efforts to implement the set goals as effectively as possible. But the author emphasizes that we should not be afraid of making mistakes as they allow us to obtain our own experience and knowledge and that helps to find the best ways to achieve goals [5].

The American scientist in the management field P.Drucker justifies several methodological approaches to the organization of management. They are the following: 1) management should be organized in such a way that the manager directs people rather than manages them; 2) managerial activity can not be standardized, therefore in different situations managers should act in different ways; 3) managers must take into account the internal aspects of the organization's development as well as influence sufficiently the external circumstances, with the appropriate level of responsibility for their own actions [3; 4].

Lee Iacocca, the American manager with many years of management experience in such giant corporations as Chrysler and Ford, 
also emphasizes the need for teamwork. In his opinion, the effectiveness of the team depends on two factors. The first one is cohesion. The second one is the common goal. Their combination enables the art of management. If the manager timely and skillfully distributes various tasks among employees, then he makes substitutions, thus he reveals every employee's talents and abilities, the team becomes a monolithic structure, whose activity becomes efficient and productive [8]. And another important point "Organizational culture has a decisive influence on employee behavior and achievement of results" $[9, \mathrm{p} .171]$.

Taking these methodological approaches into consideration, among the Ukrainian educational establishments where managers training is carried out on a high level there is the National Academy for Public Administration under the President of Ukraine, Taras Shevchenko National University of Kyiv, National Pedagogical Dragomanov University, Interregional Academy of Personnel Management and others. New approaches to the specialists-managers training are being introduced into the teaching process.

Within the educational institutions mentioned above there is a series of disciplines, which are directly related to the formation of managerial competencies. Among them there are history and theory of public management and administration, national system of public management and regulation, fundamentals of corruption prevention in public administration, fundamentals of public regulation and regulation in the economy, organizational and legal principles of state administration, psychology of management, administrative and legal principles of public management and administration, civil-law relations in the field of public management and administration, managerial counseling, information systems in public administration, state management and administration, management of the region's social and economic security, public management in the economical sphere, PR-technologies in state management, political problems of social management, managerial counseling, philosophy of management, philosophical problems of state management, social and political management, fundamentals of city management, psychology of personnel management, personnel management in political structures, public administration and public service, etc.

For instance, in 2011 the Philosophy Department of Taras Shevchenko National University of Kyiv started training of highlyqualified specialists in state management for Master degree in speciality "State Service" with daily and external educational forms as well as in the second higher education program.

From 2011 to 2017, more than 150 people were trained in various educational programs under the state order. More than 500 students of daily and external educational forms were trained at the expense of individuals 
and legal entities. $60 \%$ of these local authorities; $18 \%$ work in the specialists work in the state private sector.

authorities; $22 \%$ are employed in the

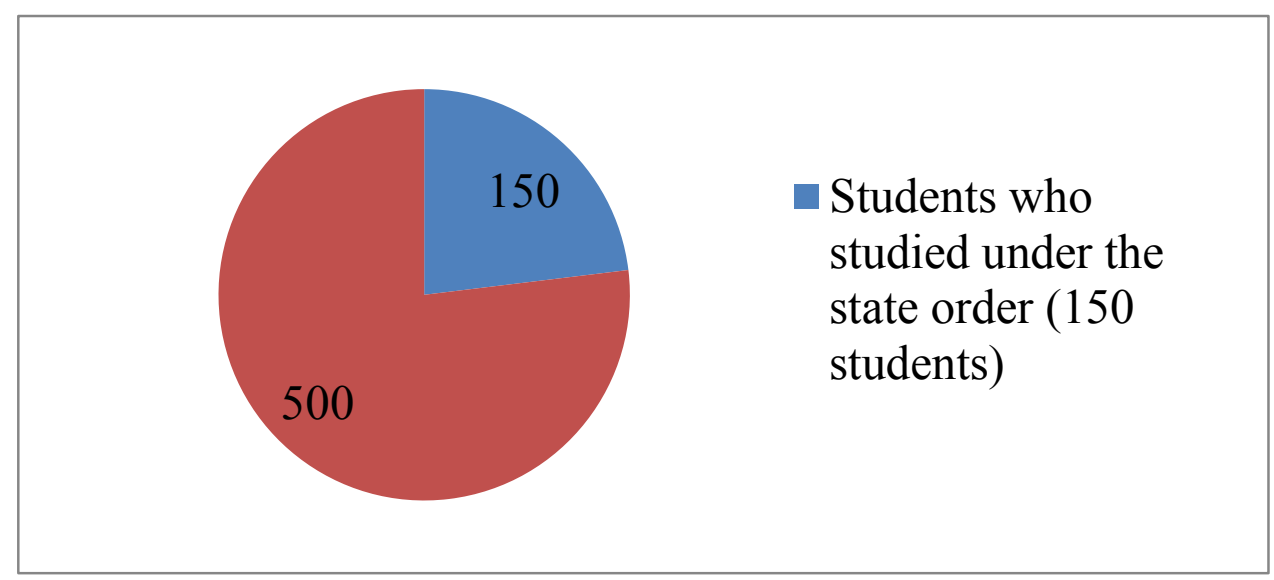

Pic. 1. The percentage of graduates who studied under the state order and for the individuals and legal entities' funds at the Faculty of Philosophy in the KNU

(speciality 281 «Pubic Management and Administration», 2011-2017).

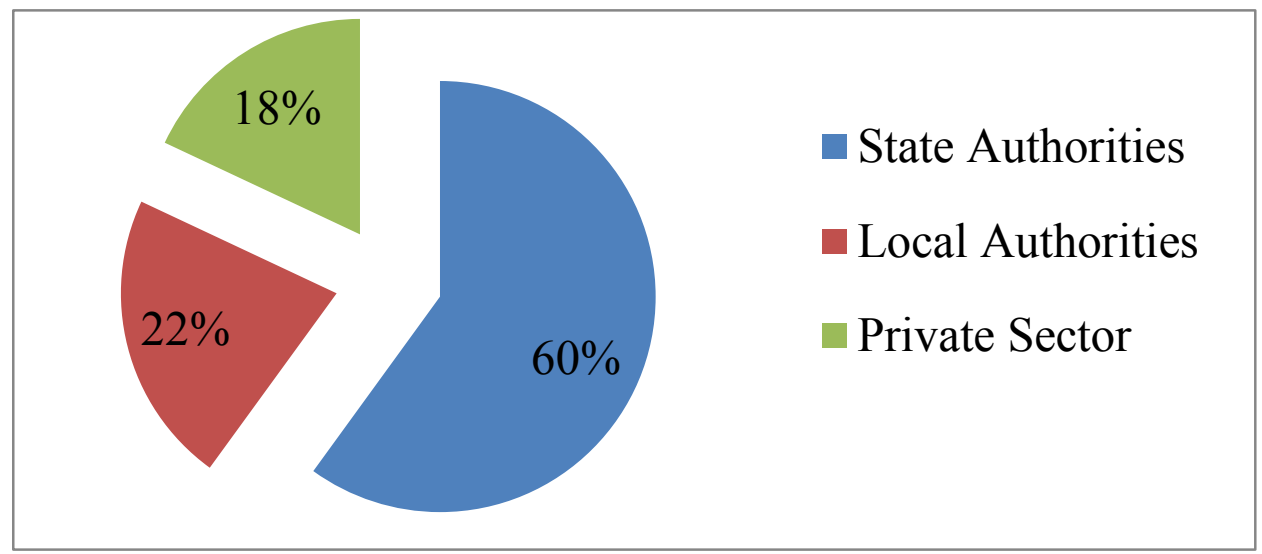

Pic. 2. The Graduates' Employment of the Philosophy Department of the KNU (speciality 281 «Public Management and Administration» (2011-2017).

According to the educational optional components, and in the curricular of the State Service and sphere of compulsory subjects about a Public Management and third part of the total amount of Administration of the Master degree credits was allocated to the disciplines program in speciality 281 "Public aimed to form managerial Management and Administration"(the competencies. And in the field of Philosophy Department of Kyiv optional disciplines, about $70 \%$ of the National University) the credits were total number of hours is provided for divided into the compulsory and profile subjects. (see pic. $3 ; 4$ ) 


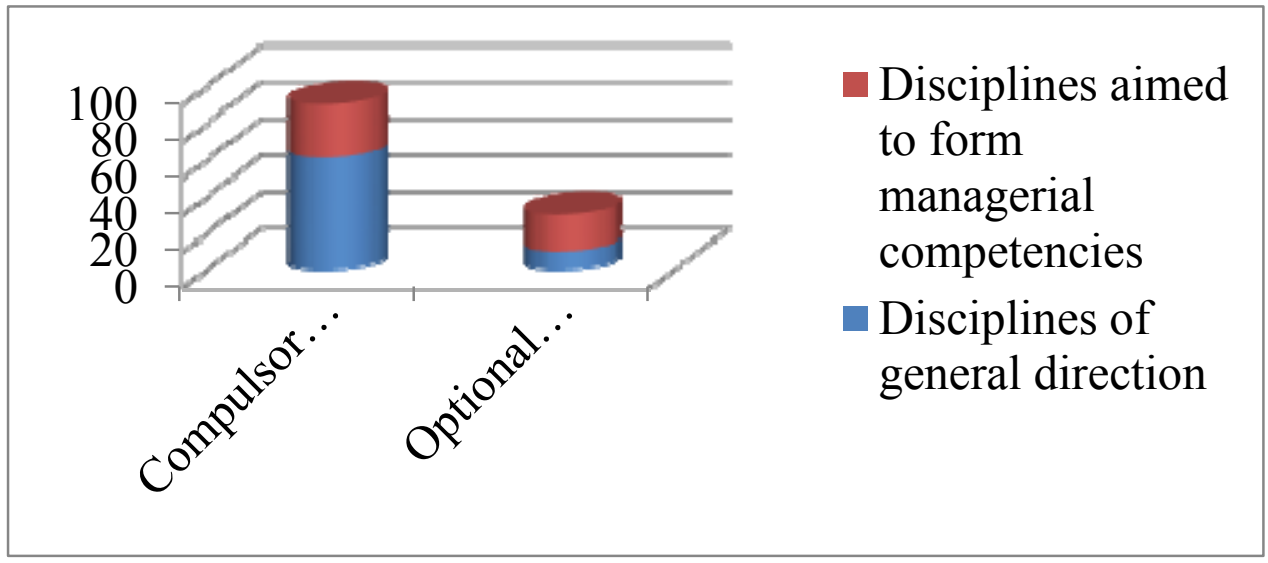

Pic. 3. Distribution of Hours (Credits) between the Compulsory and Optional Components, according to the Educational Curricular in State Service for Master degree in Speciality 281 "Public Management and Administration" (the Philosophy Department of Taras Shevchenko National University of Kyiv)

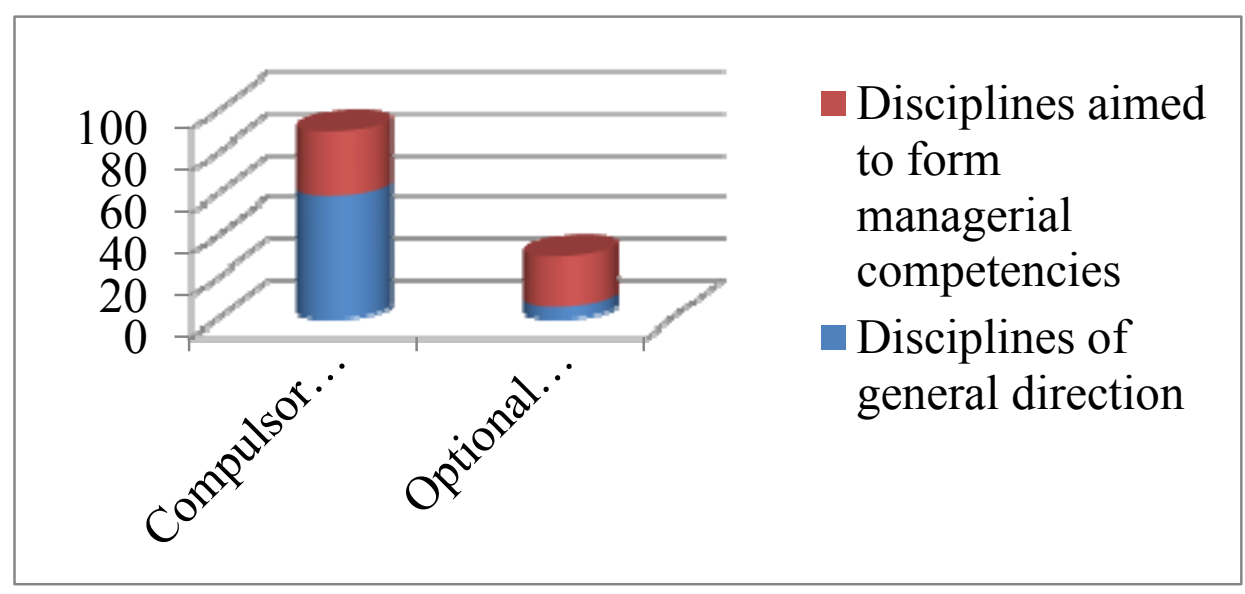

Pic. 4. Distribution of Hours (Credits) between the Compulsory and Optional

Components, according to the Educational Curricular in public Management and Administration for Master degree in Speciality 281 "Public Management and Administration"

(the Philosophy Department of Taras Shevchenko National University of Kyiv)

In addition, the Disciplinary following groups: 1) compulsory Model of the educational plan for academic disciplines; 2) disciplines training civil servants in the (optional) at the choice of faculty / postgraduate study program was institute; 3) discipline (optional) at a developed and introduced in the free choice of a postgraduate (the KNU. According to this model, all the general university list); 4) discipline disciplines were divided into four (optional) at a free choice of a 
postgraduate (the department list) [13, p. 181].

Economic and socio-political processes in Ukraine have caused the need for highly skilled management specialists. That is why "the vast majority of university students are young people for whom entering an educational institution means starting their own independent life. They learn to take responsibility and make independent decisions"[14, p.168]. Therefore, the organization of the educational process must include two main points. The first one is the conscious and purposeful, personallyoriented choice and activity of the applicant himself. The second one is availability of requests and needs on the part of specific social conditions (for example, management crisis due to radical change in production relations, new goals and nature of business relations). "Ensuring staff satisfaction in the organization is one of the most important tasks of organizational management" $[10$, p.174]. Respectively, taking these circumstances into account requires creating innovative forms and methods of training. In particular, as scientists notice, one of such factors of the national education modernization, according to globalization challenges, is the establishment of educational diplomacy, which, being based on the principles of consensus practices, can solve the global and local (national) contradictions in the development of higher education as well as the system of education management by making appropriate modernizing strategies effective [12, p. 144]. Hence, there is a vital need in reorientation of higher education connected with the training of highly skilled managers.

\section{Conclusions}

Taking into account everything mentioned above, it must be noted that the philosophy of management today is an important theoretical and methodological basis for the modern managers' training. In terms of philosophical reflection, management of any systems becomes effective through the interaction of three levels, namely: worldview level, scientificmethodological level and praxeological one. The worldview level defines the role of mentality, values and traditions in the process of management activity. At the scientific and methodological level, methods and regularities of management are determined and substantiated. At the praxeological level interconnection between the theory and practice is pointed out, emphasizing the fact that social reality makes inquiries for the latest approaches and methods of managerial activity. Thereby, the main task of modern management education is the need to prepare managers as team members who will complement each other, thanks to the appropriate communication and qualification level, and will use nonstandard (creative) approaches in tasks solving as well as will adequately respond to current social challenges. In this regard, the philosophy of management should be the methodological basis in the new paradigm in training managers of any level. 


\section{REFERENCES}

1. Adyzes, Y. (2014). Ydealniy rukovodytel. Pochemu ym nelzia stat y chto yz etoho sleduet. M.: ALPYNA PABLYShER, 360.

2. Adyzes, Y. (2014). Upravlenye yzmenenyiamy. Kak effektyvno upravliat yzmenenyiamy v obshchestve, byznese y lychnoi zhyzny. OOO Mann, Yvanov y Ferber, 368.

3. Druker, P. (2006). Entsyklopedyia menedzhmenta. M.: OOO Y. D. Vyliams, 432.

4. Druker, P. (2008). Effektyvniy rukovodytel. M.: OOO Y. D. Vyliams, 224.

5. Matsusyta, K. (2009). Pryntsypi uspekha. 2-e yzd. M.: Alpyna Byznes Buks, 126.

6. Uaitkhed, A.N. (1990). Yzbrannie raboty po fylosofyy. M.: Prohress, 720.

7. Fukuiama, F. (2007). Sylnoe hosudarstvo: Upravlenye y myrovoi poriadok v KhKhI veke. M.: AST MOSKVA: KhRANYTEL, 220.

8. Iakokka, Ly (2018). Karera menedzhera. Mynsk: Popurry, 548.

9. Andriukaitiene, Regina, Cherep A.V., Voronkova V. H., Punchenko O. P. and Kyvliuk O. P. (2018). Managing organizational culture as a factor in organizational change. Humanities Bulletin of Zaporizhzhia State Engineering Academy, 75, 169-179.

DOI https://doi.org/10.30839/2072-7941.2018.155562

10.Batranak, Genadij and Giliuviene, Virginija (2018) Satisfaction of employee with work: empirical research. Humanities Bulletin of Zaporizhzhia State Engineering Academy, $74,173-189$.

DOI: https://doi.org/10.30839/2072-7941.2018.149677

11.Cherep, Alla, Andriukaitiene, Regina and Venger, Olga (2019) New theory of management as a factor in the formation of an ecologically balanced and socially-oriented economy in the conditions of INDUSTRY 4.0. Humanities Bulletin of Zaporizhzhia State Engineering Academy, 76, 230 - 242.

DOI: https://doi.org/10.30839/2072-7941.2019.165163

12.Kyvliuk, O., Polishchuk, O. and Svyrydenko, D. but other. (2018). Educational management as education diplomacy: strategies for Ukraine Naukovyi. Visnyk NHU, 3, 139144. DOI: $10.29202 /$ nvngu/2018-3/23.

13. Nelipa, D. and Batrymenko, O. (2018). Strategy, management model and educational scientific civil servants training program in postgraduate studies of the university. Naukovyi Visnyk NHU, 2, $178-183$.

DOI: 10.29202/nvngu/2018-2/16.

14.Nelipa, D., Batrymenko, O. and Rudenko, S. but other. (2018). Higher education management in Ukraine: will generation change help us transform it faster? Naukovyi Visnyk NHU, 3,167 - 175. DOI: 10.29202/nvngu/2018-3/19.

15.http://www.philosophy.univ.kiev.ua/uploads/editor/Files/Osvit nauk progr/ Публ.управління та адміністрування.PDF

ВЛАСЕНКО Ф. П. - кандидат філософських наук, доцент кафедри філософії гуманітарних наук Київського національного університету імені Тараса Шевченка (Київ, Україна)

E-mail:vlasenkof@ukr.net, ORCID iD: 0000-0002-5272-9018

ЛЕВЧЕНЮК Є.В. - кандидат філософських наук, доцент кафедри філософії гуманітарних наук Київського національного університету імені Тараса Шевченка (Київ, Україна)

E-mail: levchenyuk@ukr.net, ORCID iD: 0000-0002-0361-6455

ТОВМАШ Д.А. - кандидат філософських наук, доцент кафедри філософії гуманітарних наук Київського національного університету імені Тараса Шевченка (Київ, Україна)

E-mail: tovmash_d@ukr.net, ORCID iD : 0000-0002-4576-0703 
ОЛЕКСИН І.Я. - кандидат філософських наук, викладач кафедри соціальногуманітарних дисциплін Національного університету фізичного виховання і спорту України (Київ, Україна)

E-mail igoroleks@ukr.net, ORCID iD: 0000-0002-6650-627X

\section{ФІЛОСОФІЯ УПРАВЛІННЯ: ОСВІТНІ СМИСЛИ І СОЦАЛЬНІ ВИКЛИКИ}

Анотація. Мета. Розкриття теоретичного i духовно-практичного потенціалу філософії управління в процесі підготовки спеціалістів у сфері публічного управління та адміністрування. Методика. У процесі дослідження використовувалися такі методи, як: аналіз, синтез, системний, компаративний, структурно-функціональний, діалектичний. Застосування синергетичного підходу в дослідженні управління уможливило розгляд останнього як складної та відкритої системи. Результати. Авторами доведено, що філософія управління нині являє собою теоретикометодологічну основу для підготовки сучасних управлінців. Також акцентовано увагу на тому, що філософія управління $є$ відмінною від теорії менеджменту, оскільки традиційний менеджмент намагається реалізувати програму підготовки менеджераодинака, який самочинно повинен керувати великими колективами, організаціями. Автори переконані, що на сьогодні це твердження є утопічним. Саме тому філософія управління має постати методологічним базисом у новій парадигмі підготовки управлінців будь-якого рівня. Наукова новизна. Уперше в науковому дискурсі зроблена спроба утвердити статус філософії управління як однієї із базових i обов'язкових дисциплін у підготовці спеціалістів у сфері публічного, державного управління та адміністрування. Доведено, що управління будь-якими системами стає ефективним завдяки взаємодії трьох рівнів, а саме: світоглядного, науковометодологічного та праксеологічного. В якості головного завдання сучасної управлінської освіти, визначено необхідність готувати управлінців як членів команди, які гідно відповідатимуть на сучасні соціальні виклики. Практична значимість. Результати дослідження мають постати орієнтирами для вдосконалення і створення нової системи підготовки сучасних управлінців, де менеджер розглядається не як керівник-одинак (індивідуал), а як член команди, в якій кожен є капіталом.

Ключові слова: філософія управління, управлінська діяльність, менеджмент, освіта, парадигма.

ВЛАСЕНКО Ф. П. - кандидат философских наук доцент кафедры философии гуманитарних наук Киевского национального университета имени Тараса Шевченка (Киев, Украина)

E-mail:vlasenkof@ukr.net, ORCID iD: 0000-0002-5272-9018

ЛЕВЧЕНЮК Е. В. - кандидат философских наук доцент кафедры философии гуманитарних наук Киевского национального университета имени Тараса Шевченка (Киев, Украина)

E-mail: levchenyuk@ukr.net, ORCID iD: 0000-0002-0361-6455

ТОВМАШ Д. А. - кандидат философских наук доцент кафедры философии гуманитарних наук Киевского национального университета имени Тараса Шевченка (Киев, Украина)

E-mail: tovmash_d@ukr.net, ORCID iD : 0000-0002-4576-0703

ОЛЕКСИН И. Я. - кандидат философских наук, преподаватель кафедры социально-гуманитарных дисциплин Национального университета физического воспитания и спорта Украины (Киев, Украина)

E-mail igoroleks@ukr.net, ORCID iD: 0000-0002-6650-627X 


\section{ФИЛОСОФИЯ УПРАВЛЕНИЯ: ОБРАЗОВАТЕЛЬНЫЕ СМЫСЛЫ И СОЦИАЛЬНЫЕ ВЫЗОВЫ}

Аннотация. Цель. Раскрытие теоретического и духовно-практического потенциала философии управления в процессе подготовки специалистов в сфере публичного управления и администрирования. Методика. В процессе исследования использовались такие методы, как: анализ, синтез, системный, компаративный, структурно-функциональный, диалектический. Применение синергетического подхода в исследовании управления позволило рассмотрение последнего как сложной и открытой системы. Результаты. Авторами доказано, что философия управления в настоящее время представляет собой теоретико-методологическую основу для подготовки современных управленцев. Также акцентировано внимание на том, что философия управления является отличной от теории менеджмента, поскольку традиционный менеджмент пытается реализовать программу подготовки менеджераодиночки, который самовольно должен управлять большими коллективами, организациями. Авторы убеждены, что сегодня это утверждение есть утопическим. Именно поэтому философия управления должна стать методологическим базисом в новой парадигме подготовки управленцев любого уровня. Научная новизна. Впервые в научном дискурсе предпринята попытка утвердить статус философии управления как одной из базовых и обязательных дисциплин в подготовке специалистов в сфере публичного, государственного управления и администрирования. Доказано, что управление любыми системами становится эффективным благодаря взаимодействию трех уровней, а именно: мировоззренческого, научно-методологического и праксеологического. В качестве главной задачи современного управленческого образования, определена необходимость готовить управленцев как членов команды, которые будут достойно отвечать на современные социальные вызовы. Практическая значимость. Результаты исследования должны стать ориентирами для совершенствования и создания новой системы подготовки современных управленцев, где менеджер рассматривается не как руководитель-одиночка (индивидуал), а как член команды, в которой каждый является капиталом.

Ключевые слова: философия управления, управленческая деятельность, менеджмент, образование, парадигма.

Стаття рекомендована до публікаиії д.філос.н., проф.В.Г.Воронковою (Запоріжжя, Україна) Надійшла до редколегії: 07.06.2019 p. Прийнята до друку: 17.06.2019 p. 